\title{
Conditional survival rate estimates of lobectomy, segmentectomy and wedge resection for stage IA1 non-small cell lung cancer: A population-based study
}

\author{
XIAOXI FAN, YICHENG LIANG, YUNPENG BAI, CHUNLU YANG and SHUN XU
}

Department of Thoracic Surgery, First Hospital of China Medical University, Shenyang, Liaoning 110001, P.R. China

Received October 22, 2019; Accepted April 27, 2020

DOI: $10.3892 / \mathrm{ol} .2020 .11713$

\begin{abstract}
Conditional survival rate (CSR) is defined as the dynamic possibility of survival, considering the changes in the survival risk over time. The present study aimed to compare the CSR of the surgical procedures for stage IA1 non-small cell lung cancer (NSCLC). Overall, data for 2,535 patients with stage IA1 NSCLC after lobectomy, segmentectomy or wedge resection were obtained from the Surveillance, Epidemiology and End Results database, and the overall survival (OS) rates were subsequently compared. CSR estimates, the possibility of patients who had already survived $x$ years, to survive further $y$ years, was calculated as $C S R=S(x+y) / S(x)$, where $S$ is the survival rate at a particular point in time. A Cox regression model and propensity-score matching were used to adjust confounding factors. There were no statistical differences in the OS among the three surgical procedures, except that OS of patients who underwent a lobectomy was improved compared with the wedge resection. The CSR of surviving to the 5th year after operation improved gradually over time. The 3 -year CSR of lobectomy or segmentectomy was higher compared with that of the wedge resection. Moreover, the 3-year CSR of segmentectomy was higher compared with that of lobectomy from the 3rd year after surgery, particularly in some specific situations, such as female sex, patients $\geq 66$ years old, patients with squamous cell carcinoma or patients with poor tumor differentiation. The present study is the first report to compare CSR following lobectomy, segmentectomy and wedge resection for patients with stage IA1 NSCLC, to the best of our knowledge. These findings indicated that lobectomy is the most conservative surgical procedure for stage IA1 NSCLC and raises questions
\end{abstract}

Correspondence to: Dr Chunlu Yang or Professor Shun Xu, Department of Thoracic Surgery, First Hospital of China Medical University, 155 Nanjingbei Street, Shenyang, Liaoning 110001, P.R. China

E-mail: clyang@cmu.edu.cn

E-mail: xushun610539@sina.com

Key words: conditional survival rate, early-stage non-small cell lung cancer, prognosis, surgical procedures, Surveillance Epidemiology and End Results regarding improved long-term prognosis of segmentectomy in some subsets of patients.

\section{Introduction}

Despite considerable progresses in the early diagnosis of early-stage lung cancer, the morbidity rate of early-stage non-small cell lung cancer (NSCLC) continues to increase (1). Since 1995, lobectomy remains the preferred option for the resection of early-stage NSCLC (2). However, advances in clinical staging modalities, surgical techniques and preoperative localization techniques have led to a resurgence of interest in sublobar resection for early-stage lung cancer.

In the absence of randomized data, clinical decisions for the increasing number of patients with early-stage NSCLC are intended to smaller extent of resection to avoid treatment-related injuries. Therefore, there is some disagreement regarding whether sublobar resection is the appropriate surgical procedure for early-stage NSCLC (3-5). Concerning stage I NSCLC, retrospective studies have reported similar long-term survival for both sublobar resection and lobectomy but a higher incidence of postoperative recurrence for sublobar resection (6-11). Notably, early-stage NSCLC with tumor sizes $\leq 1 \mathrm{~cm}$, defined as stage IA1 NSCLC according to the 8th American Joint Committee on Cancer (AJCC)/International Union Against Cancer (IUCC) non-small cell lung cancer staging system, sublobar resection preserves pulmonary function, lowers perioperative morbidity and improves long-term survival quality (12-14).

Tumor size $\leq 1 \mathrm{~cm}$ is the smallest unit of tumor (T) classification according to the 8th AJCC/IUCC non-small cell lung cancer staging system. With increasing tumor sizes, surgeons prefer to perform lobectomies. Therefore, there is a need to study the suitability of sublobar resection in stage IA1 NSCLC. Several previous studies have used cumulative survival when estimating long-term prognosis for patients with stage IA1 NSCLC after different surgical procedures $(3,15,16)$. However, cumulative survival can only provide static survival statistics, which is limited when estimating long-term survival, as the risk of death changes over time (17). In contrast to cumulative survival, the conditional survival rate (CSR) describes the dynamic possibility of survival, considering the changes in the survival risk caused by the increasing longevity $(18,19)$. 
The present study compared the CSR of patients with stage IA1 NSCLC, who had undergone lobectomy, segmentectomy and wedge resection, by utilizing the updated Surveillance, Epidemiology, and End Results Program (SEER) database. A Cox regression model and propensity-score matching (PSM) was used to adjust for confounding factors among the three surgical procedures. The present study may provide new insights into the long-term dynamic survival rate of the three surgical procedures for stage IA1 NSCLC. These results may help inform clinical decision making and provide current dynamic prognostic information.

\section{Patients and methods}

Patients. The data were obtained from the SEER database, a population-based cancer database covering above a quarter of the U.S. population (20). In total, 2,535 eligible patients with stage IA1 NSCLC were included in the present study, 1,631 of whom were women and 904 were men. Tumor-Node-Metastasis (TNM) classification was defined by the 8th edition AJCC/UICC NSCLC staging system according to the tumor size (SEER field: CSTUMSIZ) and tumor stage information in SEER (14). All patients who possessed single primary stage IA1 NSCLC, and had undergone lobectomy (SEER codes 30 to 33), segmentectomy (SEER code 22) or wedge resection (SEER code 21) between January 2004 and December 2015 were included in the present study. The exclusion criteria were as follows: i) No diagnosis confirmation microscopically; ii) received chemotherapy or radiotherapy before, during, or after the operation; iii) unknown radiation status; and iv) patients who were lost during follow-up. Fig. 1 shows the flow chart of screening. The baseline characteristics of the patients included surgical procedures, age at diagnosis, sex, ethnicity, histology, tumor sites, differentiation grade, lateral and survival time. Approval from an Institutional Review Board was not required for the present study as SEER is a publicly available database.

Statistical analysis. Student's t-tests were used for comparing continuous variables. $\chi^{2}$ tests were performed to analyze the difference between categorical variables. Overall survival (OS) rate was calculated based on the SEER fields 'Survival months' and 'Vital Status recode'. Kaplan-Meier analysis and the Renji test were used to compare the differences in OS between surgical procedures. CSR, the possibility of patients surviving further y years, who had already survived for $x$ years, was calculated by CSR $(y \mid x)=S(x+y) / S(x)$; where $\mathrm{S}$ is the OS at a particular point in time (17). For instance, the possibility of the patients who had survived one year after operation remaining alive for an additional three years was expressed as CSR (3|1), which is equivalent to the OS in the fourth year divided by that in the first year.

Competing prognostic factors were adjusted using univariate and multivariate Cox regression analyses. After that, the CSR of the three surgical procedures was estimated among factors independently associated with prognosis in the multivariate analysis. In addition, propensity score matching (PSM) was applied to minimize the potential bias caused by the existing non-randomized assignment analysis data set (21). In each PSM analysis, patients in matched groups

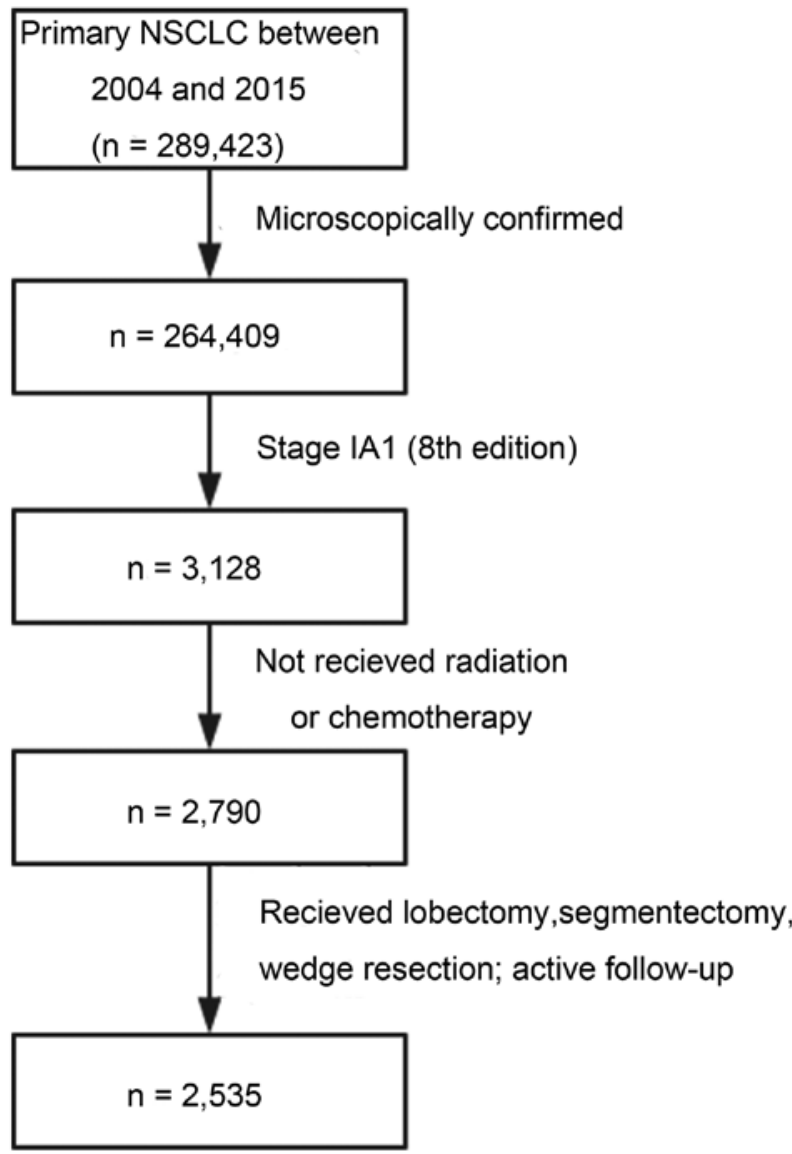

Figure 1. Flow chart for generation of the patient cohort dataset. NSCLC, non-small cell lung cancer.

were matched 1:1 using a logistic model and nearest-neighbor matching method with caliper value of PSM=0.005 $(21,22)$. Furthermore, stratification analyses were performed for the CSR of the surgical procedures, according to the clinicopathological characteristics independently associated with OS.

All the analyses were performed using SPSS version 23.0 (IBM Corp) or R program version 3.2.2 [R Foundation for Statistical Computing; (23)]. $\mathrm{P}<0.05$ was considered to indicate a statistically significant difference.

\section{Results}

Clinicopathological characteristics. Out of the 2,535 patients, 1,509 (59.5\%), 175 (6.9\%), 851 (33.6\%) had undergone lobectomy, segmentectomy and wedge resection, respectively. The median age was 67 years (IQR, 59-73 years), and the median tumor size was $0.9 \mathrm{~cm}$ (IQR, $0.8-1.0 \mathrm{~cm}$ ). The clinicopathological characteristics of these patients are summarized in Table I. Accordingly, the largest proportion of the patients had undergone lobectomy. Moreover, lobectomy was more likely to be performed in younger patients, tumors located in the middle lobe, the right lateral and tumors of definite grade. There were insignificant differences in the distribution of three surgical procedures among the ethnicity, sex and histological type (all $\mathrm{P}>0.05$; Table I).

Comparison of OS between the three surgical procedures. Using the Kaplan-Meier method and Renji test, there were 
Table I. Clinical characteristics of 2,325 patients with different surgical procedures.

\begin{tabular}{|c|c|c|c|c|c|c|}
\hline $\begin{array}{l}\text { Clinicopathological } \\
\text { characteristic }\end{array}$ & $\begin{array}{l}\text { Lobectomy } \\
\mathrm{n}=1,509(\%)\end{array}$ & $\begin{array}{l}\text { Segmentectomy } \\
\mathrm{n}=175(\%)\end{array}$ & $\begin{array}{l}\text { Wedge resection } \\
n=851(\%)\end{array}$ & $\mathrm{n}$ & $\chi^{2}$ & P-value \\
\hline Age, years & & & & & 35.022 & $<0.001^{\mathrm{a}}$ \\
\hline$\leq 65$ & $748(65.21)$ & $60(5.23)$ & $339(29.56)$ & 1,147 & & \\
\hline $66-74$ & $525(56.94)$ & $73(7.92)$ & $324(35.14)$ & 922 & & \\
\hline$\geq 75$ & $236(50.64)$ & $42(9.02)$ & $188(40.34)$ & 466 & & \\
\hline Ethnicity & & & & & 2.124 & 0.346 \\
\hline Other & $196(58.51)$ & $18(5.37)$ & $121(36.12)$ & 335 & & \\
\hline White & $1,313(59.68)$ & $157(7.14)$ & 730 (33.18) & 2,200 & & \\
\hline Sex & & & & & 2.207 & 0.332 \\
\hline Female & $971(59.53)$ & $104(6.38)$ & $556(34.09)$ & 1,631 & & \\
\hline Male & $538(59.51)$ & $71(7.85)$ & $295(32.63)$ & 904 & & \\
\hline Site in lung & & & & & 12.259 & $0.016^{\mathrm{a}}$ \\
\hline Lower lobe & $445(58.55)$ & $64(8.42)$ & $251(33.03)$ & 760 & & \\
\hline Middle lobe & $126(66.32)$ & $3(1.58)$ & $61(32.10)$ & 190 & & \\
\hline Upper lobe & 938 (59.18) & $108(6.81)$ & $539(34.01)$ & 1,585 & & \\
\hline Laterality & & & & & 19.336 & $<0.001^{\mathrm{a}}$ \\
\hline Right & $962(62.06)$ & $83(5.35)$ & 505 (32.59) & 1,550 & & \\
\hline Left & $547(55.53)$ & $92(9.34)$ & $346(35.13)$ & 985 & & \\
\hline Histology & & & & & 1.732 & 0.785 \\
\hline $\mathrm{AD}$ & $1,056(59.26)$ & $129(7.24)$ & $597(33.50)$ & 1,782 & & \\
\hline $\mathrm{SC}$ & 257 (59.35) & $25(5.77)$ & $151(34.88)$ & 433 & & \\
\hline Other & $196(61.25)$ & $21(6.56)$ & $103(32.19)$ & 320 & & \\
\hline Grade & & & & & 21.366 & $0.002^{\mathrm{a}}$ \\
\hline I & 500 (58.69) & $54(6.34)$ & $298(34.97)$ & 852 & & \\
\hline II & $554(63.17)$ & $71(8.10)$ & $252(28.73)$ & 877 & & \\
\hline III-IV & $276(59.87)$ & $26(5.64)$ & $159(34.49)$ & 461 & & \\
\hline Undetermined & $179(51.88)$ & $24(6.96)$ & $142(41.16)$ & 345 & & \\
\hline
\end{tabular}

${ }^{\mathrm{a}} \mathrm{P}<0.05$. $\mathrm{AD}$, adenocarcinoma; $\mathrm{SC}$, squamous cell carcinoma.

no significant differences in the OS between the lobectomy vs. segmentectomy and segmentectomy vs. wedge resection (all P>0.05; Fig. 2A). The 5-year overall survival rate of lobectomy, segmentectomy and wedge resection were $80.4,75.5$ and $70.6 \%$, respectively. However, the OS of lobectomy was superior to that of wedge resection $(\mathrm{P}<0.001$, Fig. 2A). The association between surgical procedures and clinicopathological characteristics was further analyzed using the Cox regression analysis. Significant prognostic factors in the univariate analysis were used in the multivariate analysis. Consequently, it was demonstrated that ethnicity, surgical procedure, sex, age, grade and histology were significantly associated with OS rate (Tables II and III).

Comparison of CSR for the three surgical procedures. The CSR of each year to the fifth year increased gradually over time (Fig. 2B). Taking lobectomy as example, the CSR (5|0), CSR (4I1), CSR (3I2), CSR (2I3), CSR (1I4) and CSR (0|5) were $80.4,84.5,88.1,91.7,96.3$ and $100 \%$, respectively. CSR $(2 \mid 3)=91.7 \%$ implied that $91.7 \%$ of the patients who underwent lobectomy and were alive in the 3 rd year would also survive for the next two years. CSR was higher in the lobectomy arm and always lowest in the wedge resection arm. Initially, the CSR in the segmentectomy group was lower compared with that in the lobectomy group but almost equivalent in the last three years. Furthermore, the 3-year CSR changed over time. For instance, 3-year CSR of wedge resection decreased to 0 on the 3rd year, then, it increased gradually (Fig. 2C).

Most of the time, among the three surgical procedures, the 3-year CSR in the lobectomy and segmentectomy groups were superior to that of the wedge resection group. The 3-year CSR in the segmentectomy arm exceeded that of the lobectomy group in the later period (Fig. 2C). PSM was used for pairwise matched surgical procedures to minimize potential bias. When matching, the patients' potential confounding baseline characteristics associated with prognosis, including age (as a continuous variable), sex, histological type and grade, were paired. The baseline characteristics of paired cohorts after PSM were well-balanced (all P>0.05; Tables IV-VI). There was no significant difference in the OS between lobectomy and segmentectomy or between segmentectomy and wedge resection (Fig. 3A-C). 

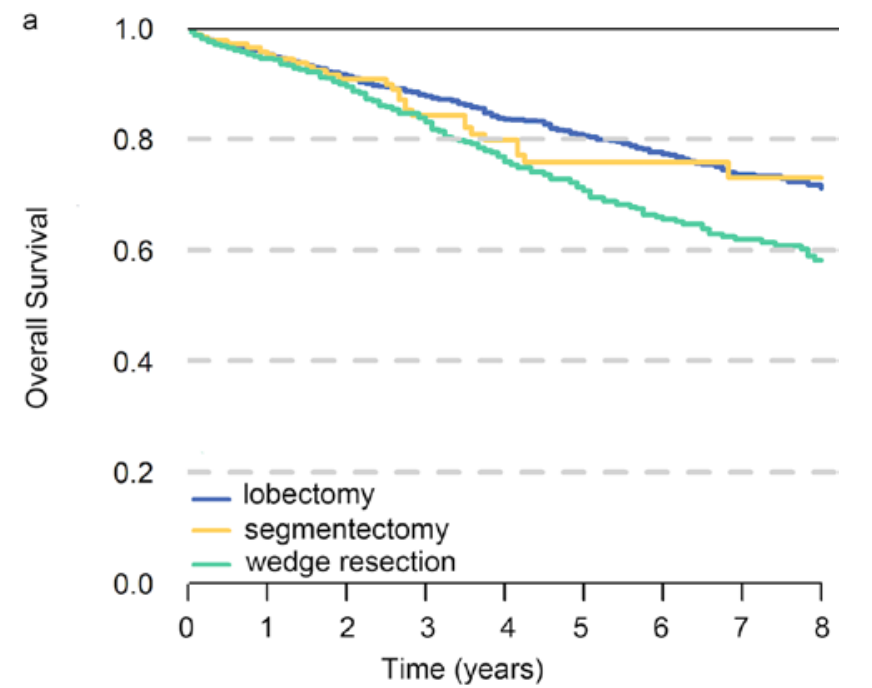

lob vs. seg: $\mathrm{HR}, 0.963 ; 95 \% \mathrm{Cl}, 0.661-1.403 ; \mathrm{P}=0.844$

lob vs. wed: $\mathrm{HR}, 0.676 ; 95 \% \mathrm{Cl}, 0.565-0.808 ; \mathrm{P}<0.001^{\star \star \star}$

seg vs. wed: $\mathrm{HR}, 0.697 ; 95 \% \mathrm{Cl}, 0.475-1.023 ; \mathrm{P}=0.066$

No. at risk:
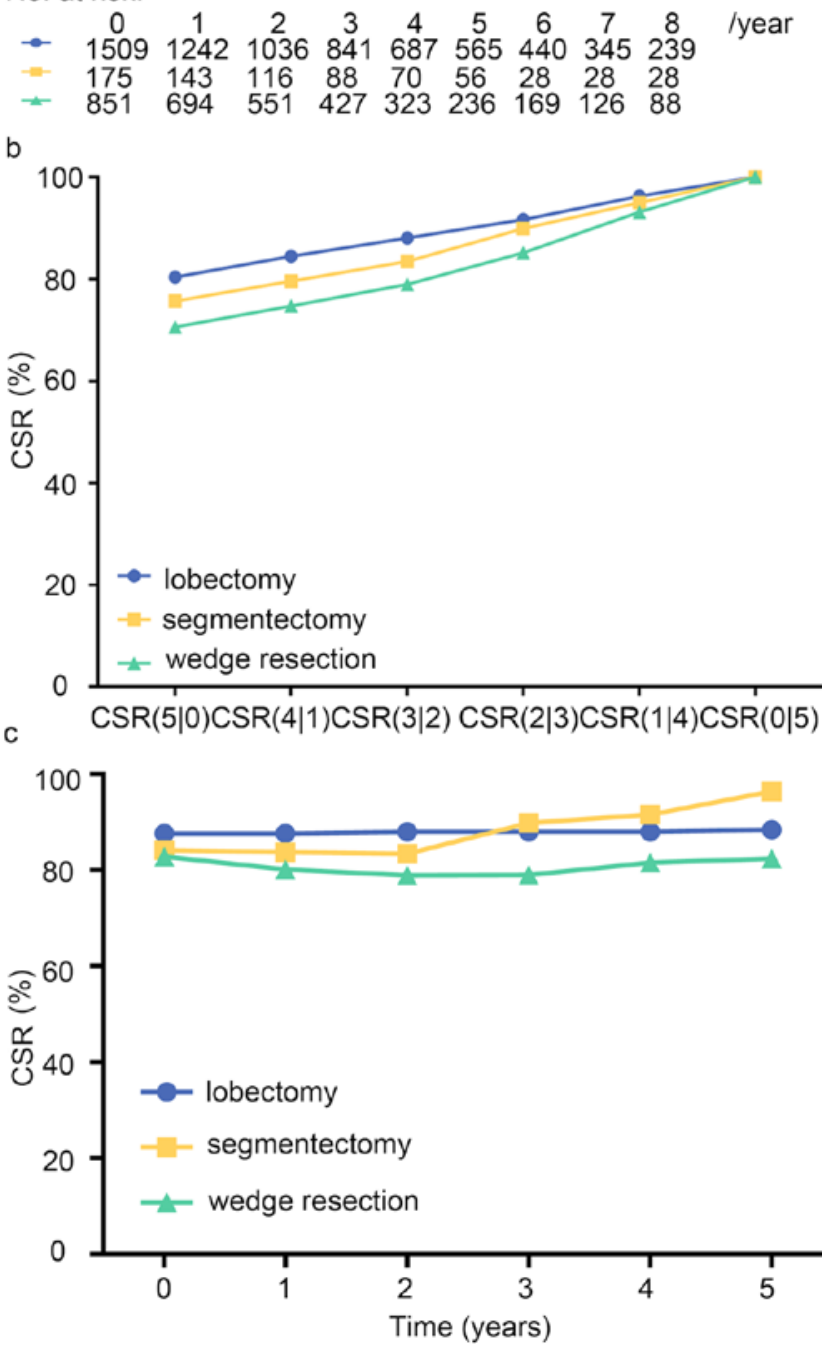

Figure 2. Comparison of overall survival and CSR between the three surgical procedures. (A) Kaplan-Meier survival curve of overall survival after lobectomy, segmentectomy and wedge resection. (B) Changes in CSR(5I0), $\operatorname{CSR}(4 \mid 1), \operatorname{CSR}(3 \mid 2), \operatorname{CSR}(2 \mid 3), \operatorname{CSR}(1 \mid 4)$ and $\operatorname{CSR}(0 \mid 5)$. CSR is defined as the probability of surviving to 5 th postoperative years after a specific time. (C) Changes in 3-year CSR. 3-year CSR is defined as the probability of surviving to the next 3 years after a specific time. CSR, conditional survival rate; HR, hazard ratio; CI, confidence interval.
Table II. Univariate Cox proportional hazard regression model for patients with stage IA1 non-small cell lung cancer.

\begin{tabular}{|c|c|c|c|}
\hline Variables & HR & $95 \% \mathrm{CI}$ & P-value \\
\hline Ethnicity & & & $0.027^{\mathrm{a}}$ \\
\hline White & Reference & - & - \\
\hline Other & 0.712 & $0.528-0.962$ & $0.027^{\mathrm{a}}$ \\
\hline Sex & & & $<0.001^{\mathrm{b}}$ \\
\hline Male & Reference & - & - \\
\hline Female & 0.607 & $0.511-0.721$ & $<0.001^{\mathrm{b}}$ \\
\hline Age, years & & & $<0.001^{\mathrm{b}}$ \\
\hline$\geq 75$ & Reference & - & - \\
\hline $66-74$ & 0.537 & $0.437-0.661$ & $<0.001^{\mathrm{b}}$ \\
\hline$\leq 65$ & 0.329 & $0.265-0.409$ & $<0.001^{\mathrm{b}}$ \\
\hline Sites in lung & & & 0.061 \\
\hline Upper & Reference & - & - \\
\hline Middle & 0.621 & $0.414-0.932$ & $0.021^{\mathrm{a}}$ \\
\hline Lower & 0.917 & $0.755-1.114$ & 0.384 \\
\hline Laterality & & & 0.926 \\
\hline Left & Reference & - & - \\
\hline Right & 1.008 & $0.846-1.202$ & 0.926 \\
\hline Histology & & & $<0.001^{\mathrm{b}}$ \\
\hline $\mathrm{AD}$ & Reference & - & - \\
\hline $\mathrm{SC}$ & 2.064 & $1.693-2.516$ & $<0.001^{\mathrm{b}}$ \\
\hline Other & 1.606 & $1.256-2.053$ & $<0.001^{\mathrm{b}}$ \\
\hline Grade & & & $<0.001^{\mathrm{b}}$ \\
\hline I & Reference & - & - \\
\hline II & 2.109 & $1.651-2.694$ & $<0.001^{\mathrm{b}}$ \\
\hline III-IV & 2.621 & $2.022-3.396$ & $<0.001^{\mathrm{b}}$ \\
\hline Undetermined & 1.942 & $1.434-2.630$ & $<0.001^{\mathrm{b}}$ \\
\hline Surgical procedure & & & $<0.001^{\mathrm{b}}$ \\
\hline Wedge resection & Reference & - & - \\
\hline Segmentectomy & 0.703 & $0.479-1.031$ & 0.071 \\
\hline Lobectomy & 0.677 & $0.566-0.811$ & $<0.001^{\mathrm{b}}$ \\
\hline
\end{tabular}

${ }^{\mathrm{a}} \mathrm{P}<0.05,{ }^{\mathrm{b}} \mathrm{P}<0.001$. HR, hazard ratio; $\mathrm{CI}$, confidence interval; $\mathrm{AD}$, adenocarcinoma; SC, squamous cell carcinoma.

However, the OS in the lobectomy group was significantly higher compared with the wedge resection group. The CSR in the lobectomy arm was higher compared with that of the segmentectomy group in the early period; however, the trend reversed in the later period. The CSR in both the lobectomy and segmentectomy groups were higher compared with the wedge resection group (Fig. 4A-C).

The 3-year CSR following stratification analyses is shown in Figs. 5 and 6. In each subgroup analysis, the CSR of the segmentectomy and lobectomy groups were very close but overall higher compared with that of the wedge resection group. Among the patients aged $<65$-years, the CSR rates of the segmentectomy and the lobectomy groups were almost equal. Regarding age increase, the CSR was lower in the segmentectomy group compared with the lobectomy group in the early period, but the trend reversed in the later period. 
Table III. Multivariate cox regression analysis for patients with stage IA1 non-small cell lung cancer.

\begin{tabular}{lccc}
\hline Variables & HR & $95 \%$ CI & P value \\
\hline Race & & & 0.163 \\
White & Reference & - & - \\
Other & 0.807 & $0.597-1.091$ & 0.163 \\
Sex & & & $<0.001^{\mathrm{c}}$ \\
Male & Reference & - & - \\
Female & 0.636 & $0.534-0.758$ & $<0.001^{\mathrm{c}}$ \\
Age, years & & & $<0.001^{\mathrm{c}}$ \\
$\geq 75$ & Reference & - & - \\
66-74 & 0.558 & $0.452-0.688$ & $<0.001^{\mathrm{c}}$ \\
$\leq 65$ & 0.366 & $0.292-0.457$ & $<0.001^{\mathrm{c}}$ \\
Histology & & & $0.012^{\mathrm{a}}$ \\
AD & Reference & - & - \\
SC & 1.369 & $1.099-1.704$ & $0.005^{\mathrm{b}}$ \\
Other & 1.280 & $0.988-1.658$ & 0.062 \\
Grade & & & $<0.001^{\mathrm{c}}$ \\
I & Reference & - & - \\
I & 1.827 & $1.416-2.357$ & $<0.001^{\mathrm{c}}$ \\
III-IV & 1.942 & $1.463-2.577$ & $<0.001^{\mathrm{c}}$ \\
Undetermined & 1.815 & $1.338-2.461$ & $<0.001^{\mathrm{c}}$ \\
Surgical procedure & & & $0.003^{\mathrm{b}}$ \\
Wedge resection & Reference & - & - \\
Segmentectomy & 0.704 & $0.48-1.034$ & 0.073 \\
Lobectomy & 0.737 & $0.615-0.883$ & $0.001^{\mathrm{b}}$ \\
\hline
\end{tabular}

${ }^{\mathrm{a}} \mathrm{P}<0.05,{ }^{\mathrm{b}} \mathrm{P}<0.01,{ }^{\mathrm{c}} \mathrm{P}<0.001$. HR, hazard ratio; $\mathrm{CI}$, confidence interval; $\mathrm{AD}$, adenocarcinoma; $\mathrm{SC}$, squamous cell carcinoma.

There was no statistical difference in the CSR between the three surgical procedure groups in Grade I. The higher the grade, the lower CSR in the segmentectomy group compared with lobectomy arm in the early period. The CSR in female patients in the segmentectomy group was lower compared with that in the lobectomy group in the early period, but the pattern reversed in the late period. However, in male patients, the CSR rate in the lobectomy group was higher compared with the segmentectomy or wedge resection groups. In the adenocarcinoma patient-group, the CSR in the lobectomy group was also higher compared with the segmentectomy or wedge resection groups (Fig. 5B). However, in patients with the squamous cell carcinoma and other types, CSR was lower in the segmentectomy compared with in the lobectomy arm in the first two years; but this trend reversed after two years of operation (Fig. 5D and F).

\section{Discussion}

The increasing incidence rate of early-stage NSCLC has led to conflicting arguments regarding the most effective surgical procedure, particularly for small tumors, such as T1a. In the present study, it was reported that that the 5-year overall survival rates for patients with stage IA1 NSCLC, who underwent different surgical procedures, varies from $70-80 \%$, which is consistent with findings from previous studies $(3,15)$. Further, lobectomy is superior to wedge resection surgical procedure in terms of OS $(24,25)$, which is consistent with the present findings. Previous studies indicated that the effectiveness of sublobar resection and lobectomy are equivalent for stage IA1 NSCLC $(5,6,26)$. However, these studies estimated the long-term prognosis of patients with stage IA1 NSCLC using cumulative survival rate, without taking into account the postoperative follow-up information. However, the mortality risk after surgery is dynamic throughout the course of follow-up (27). Therefore, cumulative survival cannot provide accurate estimates of long-term prognosis for oncologists and patients, particularly when patients survive extra years. Compared with cumulative survival, the CSR method reflects the changes in survival probability as the duration of follow-up increases, and is therefore useful in predicting prognosis.

In the present study, it was found that CSR increases as survival time is prolonged overall. This could be due to the elapse of time, and there is a natural selection effect on the initial population as patients with the highest risk of death would die earlier, therefore over time a healthier population remains. However, CSR may decrease during this particular period. To explain this phenomenon, it was assumed that the cumulative survival rate of patients are a, b, c, d, e, f, $\mathrm{g}, \mathrm{h}$ and $\mathrm{i}$ in 0 to the 8th year, which could imply, $\mathrm{a} \geq \mathrm{b} \geq \mathrm{c}$ $\geq \mathrm{d} \geq \mathrm{e} \geq \mathrm{f} \geq \mathrm{g} \geq \mathrm{h} \geq \mathrm{i}$. According to the calculation of the CSR, CSR (310)=d/a, CSR(3|1)=e/b and so forth. For example, regarding the CSR curve between years $0-1$, when the curve raises, CSR (3|1)-CSR (3|0)=e/b $-\mathrm{d} / \mathrm{a}=(\mathrm{ae}-\mathrm{bd}) / \mathrm{ab}>0$, namely $\mathrm{b} / \mathrm{a}<\mathrm{e} / \mathrm{d}$. This implies that the difference between $\mathrm{b}$ and $\mathrm{a}$ is larger than the difference between e and d, suggesting that the mortality risk in the later 3 years is lower compared with the first 2 years, demonstrating an improved long-term prognosis after the given time point. When curve slopes downwards, the long-term prognosis after that time point worsens. When curve remains steady, it implies that the death risk is almost equal in first 4 years. This is because the long-term prognosis after this time point gets worse compared with the short-term prognosis near this time point. Based on the derivation, it was reported that the death risk in lobectomy procedure stabilized over time. This implied that lobectomy is the most conservative and appropriate surgical option in stage IA1 NSCLC. However, with the elapse of time, the CSR of segmentectomy arm exceeded that of the lobectomy procedure, suggesting better long-term prognosis of segmentectomy.

CSR can be used to more accurately describe the current prognosis for patients who have survived several years after the surgery. Based on the results of the present study, patients could only be told the expected 5 -year survival rate calculated from post-lobectomy was $80.4 \%$. However, this survival rate may be inaccurate, considering the 5 -year cumulative survival estimate from the postoperation does not consider the extra survival time. Calculating the CSR (3/2) appropriately addresses this issue. For example, the lobectomy CSR (3/2) was $88.1 \%, 7.7 \%$ higher compared with the OS in the 5th year (80.4\%).

In the present study, the CSR (5|0), CSR (4|1), CSR (3|2), CSR (2|3), CSR (114) and CSR (0|5) that are the possibilities of surviving to 5th year after each postoperative year, revealed stepwise improvement in all the surgical procedure groups. 
Table IV. Balance between groups of patients undergoing lobectomy and segmentectomy for T1a before and after propensity score matching.

\begin{tabular}{|c|c|c|c|c|c|c|}
\hline \multirow[b]{2}{*}{ Variables } & \multicolumn{3}{|c|}{ Full cohort } & \multicolumn{3}{|c|}{ Matched cohort } \\
\hline & $\begin{array}{c}\text { Lobectomy, } \\
n=1,509\end{array}$ & $\begin{array}{l}\text { Segmentectomy, } \\
n=175\end{array}$ & P-value & $\begin{array}{l}\text { Lobectomy, } \\
\qquad n=174\end{array}$ & $\begin{array}{l}\text { Segmentectomy, } \\
n=174\end{array}$ & P-value \\
\hline Age, years, mean \pm SD) & $64.55(9.77)$ & $67.73(9.84)$ & $<0.001^{\mathrm{a}}$ & $67.60(9.46)$ & $67.60(9.72)$ & 0.996 \\
\hline Sex, n (\%) & & & 0.200 & & & 0.131 \\
\hline Female & $971(64.35)$ & $104(59.43)$ & & $90(51.72)$ & $104(59.77)$ & \\
\hline Male & $538(35.65)$ & $71(40.57)$ & & $84(48.28)$ & $70(40.23)$ & \\
\hline Histology, n (\%) & & & 0.567 & & & 0.332 \\
\hline $\mathrm{AD}$ & $1,056(69.98)$ & $129(73.71)$ & & $117(67.24)$ & $129(74.14)$ & \\
\hline $\mathrm{SC}$ & $257(17.03)$ & $25(14.2)$ & & $33(18.97)$ & $24(13.79)$ & \\
\hline Other & $196(12.99)$ & $21(12.00)$ & & $24(13.79)$ & $21(12.07)$ & \\
\hline Grade, n (\%) & & & 0.502 & & & 0.751 \\
\hline I & $500(33.13)$ & $54(30.86)$ & & $58(33.33)$ & $54(31.03)$ & \\
\hline II & $554(36.71)$ & $71(40.57)$ & & $62(35.63)$ & $71(40.80)$ & \\
\hline III-IV & $276(18.29)$ & $26(14.86)$ & & $30(17.24)$ & $25(14.37)$ & \\
\hline Undetermined & $179(11.86)$ & $24(13.71)$ & & $24(13.79)$ & $24(13.79)$ & \\
\hline
\end{tabular}

${ }^{\mathrm{a}} \mathrm{P}<0.001$. SD, standard deviation; $\mathrm{AD}$, adenocarcinoma; SC, squamous cell carcinoma.

Table V. Balance between groups of patients undergoing lobectomy and wedge resection for T1a before and after propensity score matching.

\begin{tabular}{|c|c|c|c|c|c|c|}
\hline \multirow[b]{2}{*}{ Variables } & \multicolumn{3}{|c|}{ Full cohort } & \multicolumn{3}{|c|}{ Matched cohort } \\
\hline & $\begin{array}{l}\text { Lobectomy, } \\
\mathrm{n}=1,509\end{array}$ & $\begin{array}{l}\text { Wedge resection, } \\
\qquad \mathrm{n}=851\end{array}$ & P-value & $\begin{array}{l}\text { Lobectomy, } \\
\qquad n=826\end{array}$ & $\begin{array}{l}\text { Wedge resection, } \\
\qquad \mathrm{n}=826\end{array}$ & P-value \\
\hline Age, years, mean $\pm(S D)$ & $64.55(9.78)$ & $67.10(9.99)$ & $<0.001^{\mathrm{a}}$ & $66.47(9.62)$ & $66.71(9.83)$ & 0.627 \\
\hline Sex, n (\%) & & & 0.630 & & & 0.240 \\
\hline Female & $971(64.35)$ & $556(65.33)$ & & $514(62.23)$ & $537(65.01)$ & \\
\hline Male & $538(35.65)$ & $295(34.67)$ & & $312(37.77)$ & 289 (34.99) & \\
\hline Histology, n (\%) & & & 0.779 & & & 0.883 \\
\hline $\mathrm{AD}$ & $1,056(69.98)$ & $597(70.15)$ & & 573 (69.37) & $576(69.73)$ & \\
\hline $\mathrm{SC}$ & $257(17.03)$ & $151(17.74)$ & & 155 (18.77) & $148(17.92)$ & \\
\hline Other & 196 (12.99) & $103(12.10)$ & & $98(11.86)$ & $102(12.35)$ & \\
\hline Grade, n (\%) & & & $<0.001^{\mathrm{a}}$ & & & 0.094 \\
\hline I & $500(33.13)$ & $298(35.02)$ & & $248(30.02)$ & $296(35.84)$ & \\
\hline II & $554(36.71)$ & $252(29.61)$ & & 275 (33.29) & $249(30.15)$ & \\
\hline III-IV & $276(18.29)$ & $159(18.68)$ & & $173(20.94)$ & $158(19.13)$ & \\
\hline Undetermined & $179(11.86)$ & $142(16.69)$ & & $130(15.74)$ & $123(14.89)$ & \\
\hline
\end{tabular}

${ }^{\mathrm{a}} \mathrm{P}<0.001$. SD, standard deviation; $\mathrm{AD}$, adenocarcinoma; SC, squamous cell carcinoma.

Moreover, the lobectomy CSR was $>90 \%$ in the 3 rd year, followed by segmentectomy and wedge resection in the 4th year. This implied that a significant number of patients with stage IA1 NSCLC who survived 3 or 4 years postsurgery remained alive at the 5 th year. Hence, this information could be used by clinicians to answer patient questions concerning their 5-year postoperative survival. Psychologically, the ability of patients to more accurately conceptualize their changing risk profile is beneficial, enhancing their confidence to triumph over disease and reduce their anxiety about survival (28).

Comparing the CSR of surgical procedures before and after PSM, it was demonstrated that the CSR of lobectomy and segmentectomy were all higher compared with that of the wedge resection. This could be due to insufficient surgical 


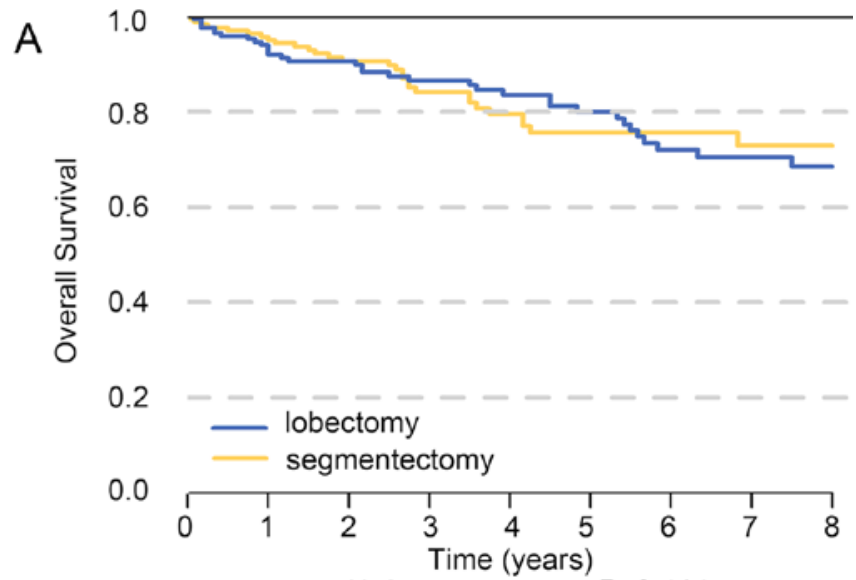

lob vs seg: $\mathrm{HR}, 0.822 ; 95 \% \mathrm{Cl}, 0.513-1.316 ; \mathrm{P}=0.414$

No. at risk:


wed vs lob: HR, 1.233; $95 \% \mathrm{Cl}, 1.004-1.515 ; \mathrm{P}=0.046^{*}$

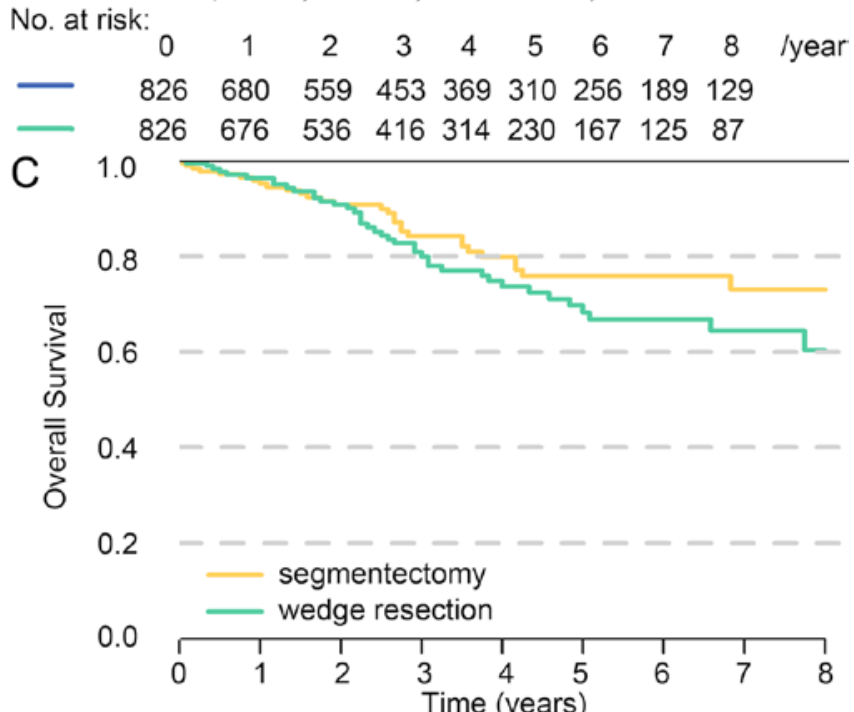

seg vs wed: $\mathrm{HR}, 0.757 ; 95 \% \mathrm{Cl}, 0.471-1.215 ; \mathrm{P}=0.249$

No. at risk:

$\begin{array}{ccccccccccc}0 & 1 & 2 & 3 & 4 & 5 & 6 & 7 & 8 & \text { /year } \\ - & 175 & 143 & 116 & 88 & 70 & 56 & 56 & 56 & 28 & \\ -175 & 141 & 116 & 87 & 63 & 49 & 48 & 27 & 16 & \end{array}$

Figure 3. Comparison of overall survival between pairwise surgical procedures after PSM. Kaplan-Meier survival curve of overall survival of (A) lobectomy vs. segmentectomy, (B) wedge resection vs. lobectomy and (C) segmentectomy vs. wedge resection. PSM, propensity-score matching; HR, hazard ratio; CI, confidence interval.
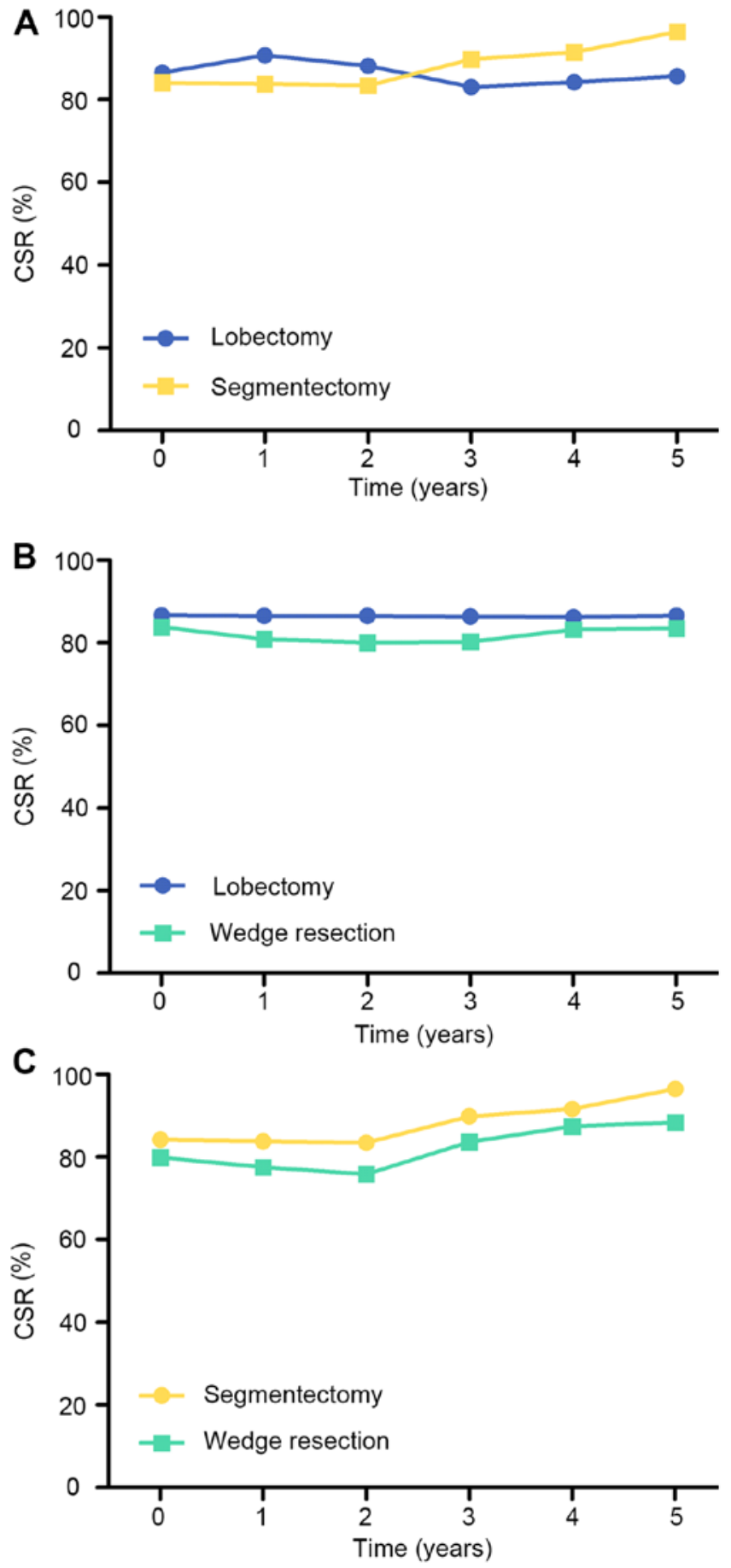

Figure 4. Comparison of CSR between pairwise surgical procedures. The changes in 3-year CSR of (A) lobectomy and segmentectomy, (B) lobectomy and wedge resection and (C) segmentectomy and wedge resection after PSM. CSR, conditional survival rate; PSM, propensity-score matching.

margins and nodes sampled during wedge resection. Notably, the CSR of segmentectomy was lower compared with that of lobectomy in the first two years but became higher after the 3rd year. This may be due to segmentectomy underestimating NSCLC stage due to deficient lymphadenectomy for hilar lymph nodes compared with lobectomy (29) and that a proportion of the patients were exposed to high risk of recurrence or metastasis and died in the first two years. The remaining patients have a better prognosis with retention of the pulmonary function (30). Altogether, segmentectomy may 
Table VI. Balance between groups of patients undergoing segmentectomy and wedge resection for T1a before and after propensity score matching.

\begin{tabular}{|c|c|c|c|c|c|c|}
\hline \multirow[b]{2}{*}{ Variables } & \multicolumn{3}{|c|}{ Full cohort } & \multicolumn{3}{|c|}{ Matched cohort } \\
\hline & $\begin{array}{l}\text { Segmentectomy, } \\
\mathrm{n}=175\end{array}$ & $\begin{array}{l}\text { Wedge resection, } \\
\qquad \mathrm{n}=851\end{array}$ & P-value & $\begin{array}{l}\text { Segmentectomy, } \\
n=175\end{array}$ & $\begin{array}{l}\text { Wedge resection, } \\
\qquad \mathrm{n}=175\end{array}$ & P-value \\
\hline Age, years, mean $( \pm$ SD) & $67.33(9.85)$ & $67.10(9.99)$ & 0.445 & $67.73(9.85)$ & $66.54(9.29)$ & 0.246 \\
\hline Sex, n $(\%)$ & & & 0.137 & & & 0.516 \\
\hline Female & $104(59.43)$ & $556(65.33)$ & & $104(59.43)$ & $98(56.00)$ & \\
\hline Male & $71(40.57)$ & $295(34.67)$ & & $71(40.57)$ & $77(44.00)$ & \\
\hline Histology, n (\%) & & & 0.529 & & & 0.177 \\
\hline $\mathrm{AD}$ & $129(73.71)$ & $597(70.15)$ & & $129(73.71)$ & $123(70.29)$ & \\
\hline $\mathrm{SC}$ & $25(14.29)$ & $151(17.74)$ & & $25(14.29)$ & $37(21.14)$ & \\
\hline Other & $21(12.00)$ & $103(12.10)$ & & $21(12.00)$ & $15(8.57)$ & \\
\hline Grade, n (\%) & & & $0.041^{\mathrm{a}}$ & & & 0.649 \\
\hline I & $54(30.86)$ & $298(35.02)$ & & $54(30.86)$ & $49(28.00)$ & \\
\hline II & $71(40.57)$ & $252(29.61)$ & & $71(40.57)$ & $65(37.14)$ & \\
\hline III-IV & $26(14.86)$ & $159(18.68)$ & & $26(14.86)$ & $33(18.86)$ & \\
\hline Undetermined & $24(13.71)$ & $142(16.69)$ & & $24(13.71)$ & $28(16.00)$ & \\
\hline
\end{tabular}

${ }^{\mathrm{a}} \mathrm{P}<0.05$. SD, standard deviation; $\mathrm{AD}$, adenocarcinoma; $\mathrm{SC}$, squamous cell carcinoma.

come at the price of insufficient lymphadenectomy but provide a compromise, for example greater conservation of the pulmonary function with promising long-term survival outcome.

The present study identified several factors, including age, sex, grade, histology and surgical procedures that were significantly associated with OS. This may partially explain heterogeneous survival of patients who undergo the same surgical procedure. To evaluate the effect of different operations on different factors, the CSR of the three surgical procedures was calculated based on stratification. In each subgroup analysis, the CSR of segmentectomy and lobectomy were higher compared with in wedge resection. Patients who initially had favorable clinicopathological characteristics, including $\leq 65$ years-old or, grade I and who underwent segmentectomy, had CSR equivalent to that of the lobectomy group. However, patients with unfavorable conditions, such as advanced age displayed an expected trend, in that the segmentectomy CSR was lower compared with the lobectomy CSR in the early period but became higher in the later period. In patients with squamous cell carcinoma or other histological types, a similar trend was reported. In the adenocarcinoma group, the higher lobectomy CSR compared with that in the segmentectomy arm may be associated with that early metastasis in adenocarcinoma. Moreover, the insufficient lymph node dissection in sublobar resection does not favor prognosis (31). Further, in males, the segmentectomy CSR was equivalent to the lobectomy CSR overall. On the contrary, in females, the segmentectomy CSR was lower compared with lobectomy CSR in the early period but became higher in the later period. Similar results have been reported in lung cancer resection, however the cause of these differences remains unclear (32-34). Therefore, there is a need to conduct studies on the response of different sexes to surgical procedures as well as tumor biology associated with physiological status in different sexes.

To the best of our knowledge, the present study is the first to assess CSR among patients with stage IA1 NSCLC using surgical procedures as a covariate. The CSR of surgical procedures based on the stratification of different prognostic factors was investigated. The aim of the present study was not to change the treatment paradigm, but to encourage wider application of CSR, that has not been studied before for patients with stage IA1 NSCLC, by comparing survival outcomes. The present results may contribute an additional insight to the prognosis of stage IA1 NSCLC, considering the dynamic survival probability.

There are limitations to the present study, inherent with using the SEER database. Firstly, the study had a retrospective design using SEER database, which presents with unavoidable selection bias. Although the apparent bias was compensated for using the Cox regression model and propensity-matched analysis, there still may have been some unknown latent biases, including preoperative physical condition, performance status and comorbidities among the treatment arms (35). Therefore, the impact of these covariates on the present findings could not be determined. Secondly, analysis was based on the postoperative pathological stage rather than the clinical stage. The clinical stage serves a more crucial role in decision making on the most appropriate surgical procedure to be administered to future patients. Thirdly, sublobar resection is more likely to apply to patients with poor physical status, for whom lobectomy is unsuitable (36). This may have caused some bias when comparing the prognosis of different surgical procedures. To minimize the impact of these aforementioned limitations, high-quality prospective studies need to be 
A

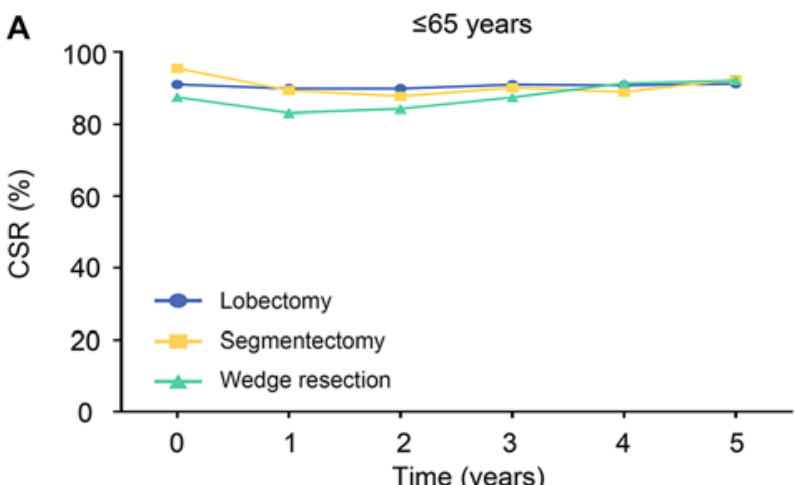

Number at risk:

$\begin{array}{clllllc}- & 748 & 634 & 535 & 434 & 369 & 300 \\ - & 60 & 60 & 49 & 39 & 30 & 26 \\ - & 339 & 277 & 218 & 162 & 129 & 104\end{array}$

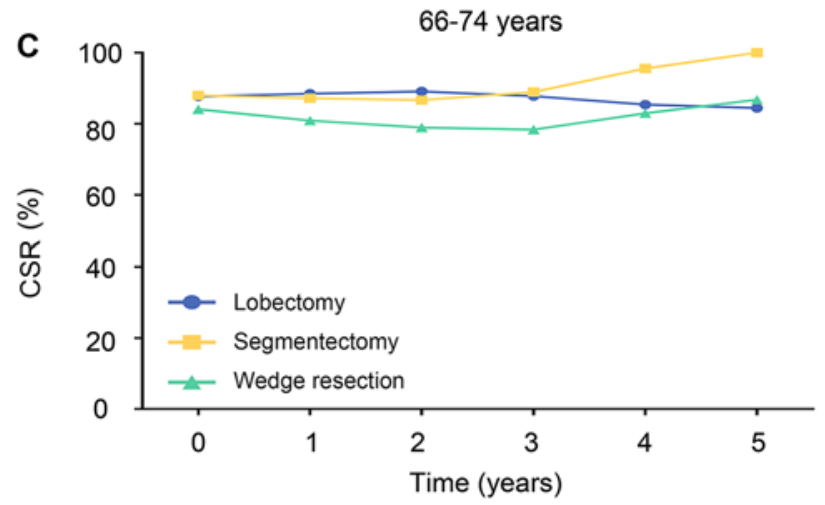

Number at risk:

$\begin{array}{lllllll}\longrightarrow & 525 & 433 & 363 & 292 & 245 & 194 \\ - & 73 & 58 & 49 & 38 & 27 & 23 \\ - & 324 & 273 & 219 & 171 & 127 & 93\end{array}$

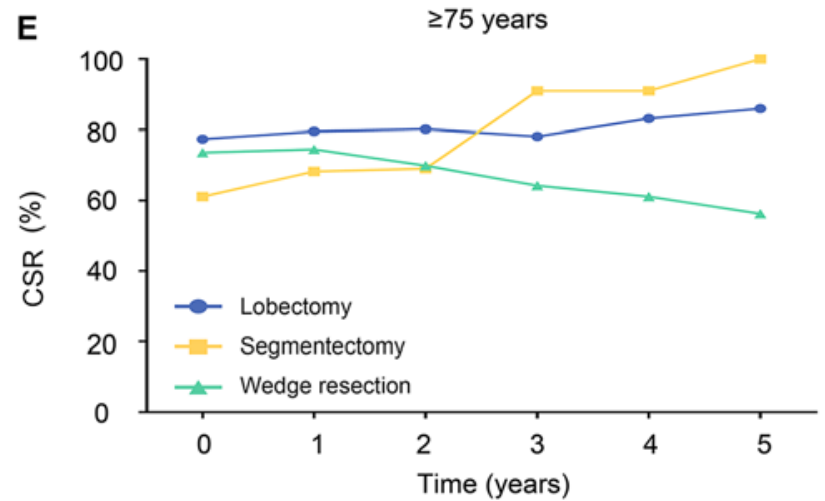

Number at risk:

$\begin{array}{lllllll}- & 236 & 183 & 144 & 126 & 87 & 73 \\ - & 42 & 32 & 27 & 16 & 16 & 11 \\ - & 188 & 149 & 125 & 94 & 71 & 47\end{array}$
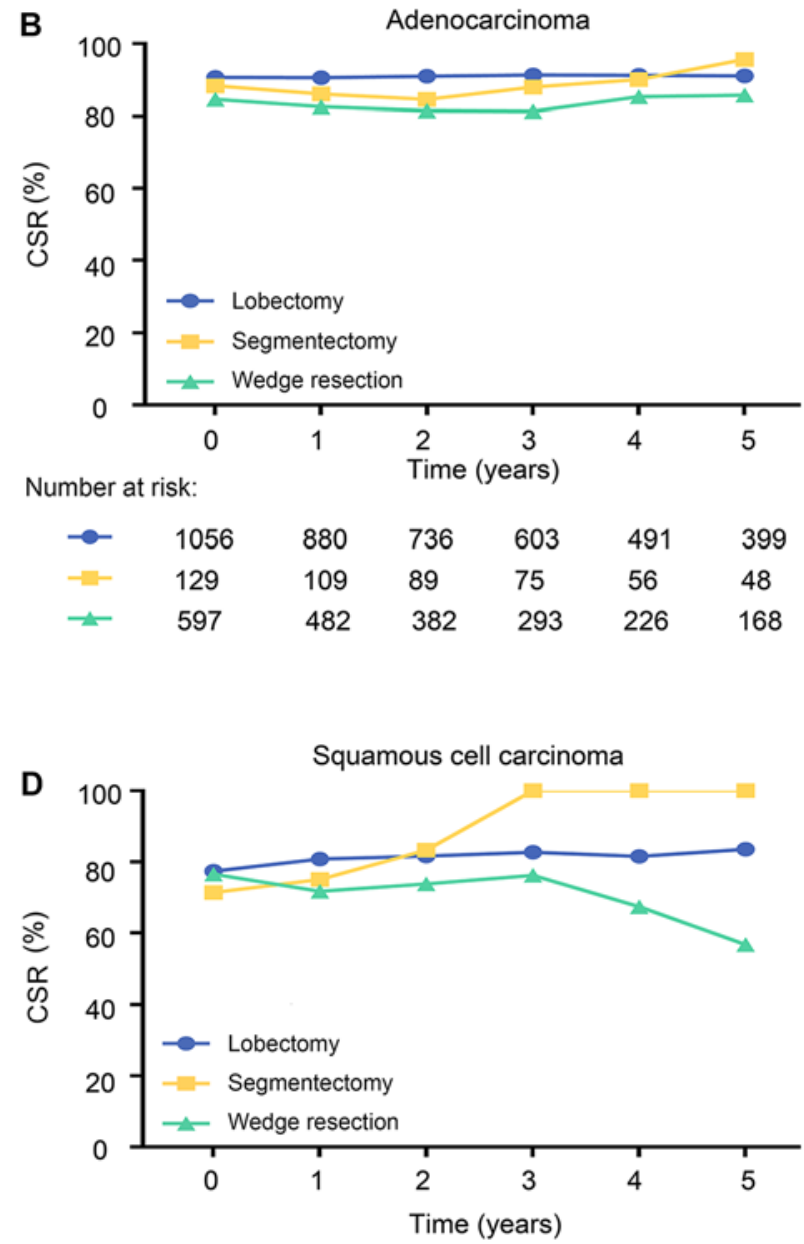

Number at risk:

$\begin{array}{lllllll}\longrightarrow & 257 & 213 & 180 & 142 & 118 & 103 \\ - & 25 & 21 & 19 & 11 & 11 & 11 \\ - & 151 & 132 & 100 & 83 & 58 & 40\end{array}$

$\mathbf{F}$

$\mathbf{F}$

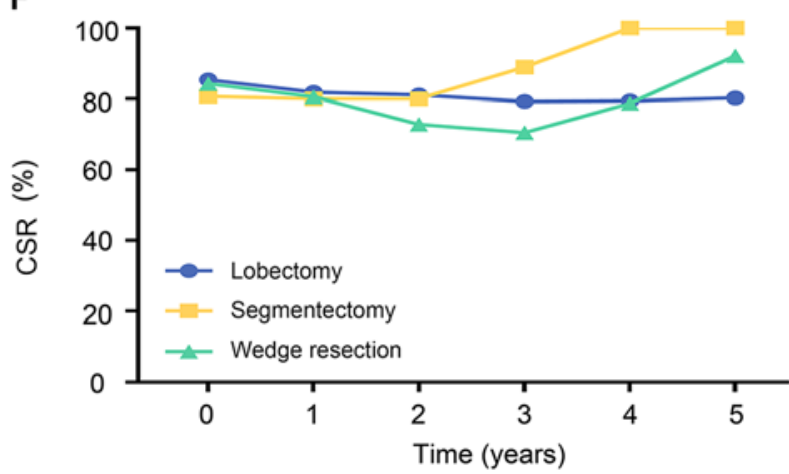

Number at risk:

$\begin{array}{ccccccc}\rightarrow & 196 & 150 & 123 & 94 & 82 & 68 \\ - & 21 & 18 & 18 & 10 & 9 & 9 \\ - & 103 & 84 & 69 & 54 & 41 & 29\end{array}$

Figure 5. Comparison of CSR among three surgical procedures based on stratification according to age and histological type. The changes in 3-year CSR of (A) $<65$ year-old, (C) $66 \leq a g e \leq 74$ - and (E) $>75$ years old, (B) adenocarcinoma; (D) squamous cell carcinoma and (F) other histological types. CSR, conditional survival rate.

conducted to validate the present findings. Furthermore, the CSR is a semiquantitative concept, so it can only be compared according to number, without indicating a statistically significant difference. 
A

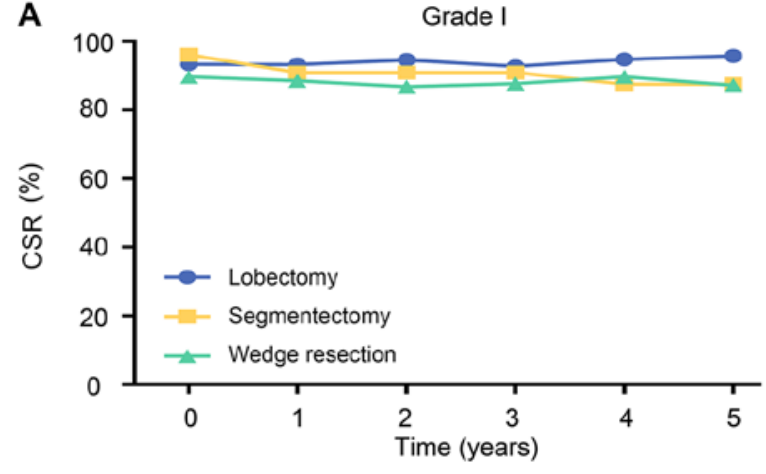

Number at risk:

$\begin{array}{lllllll}- & 500 & 413 & 350 & 281 & 224 & 177 \\ - & 54 & 49 & 49 & 49 & 22 & 22 \\ - & 298 & 257 & 197 & 147 & 119 & 83\end{array}$

C

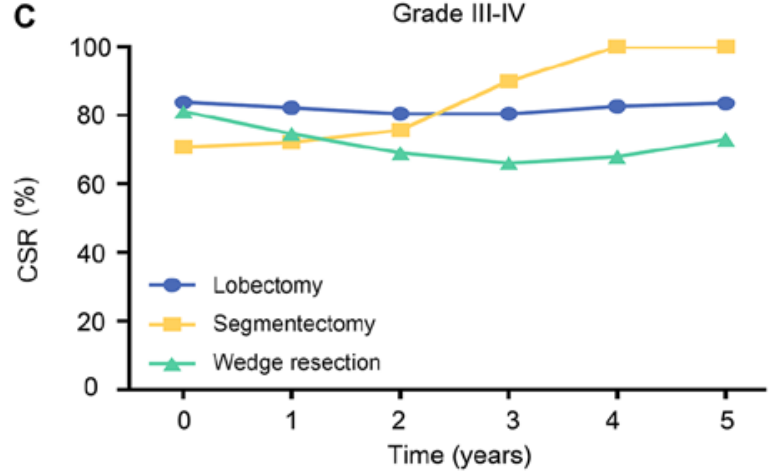

Number at risk:

$\begin{array}{lllllll}- & 276 & 237 & 203 & 167 & 140 & 116 \\ - & 26 & 23 & 21 & 17 & 10 & 10 \\ - & 159 & 133 & 113 & 96 & 69 & 50\end{array}$

E

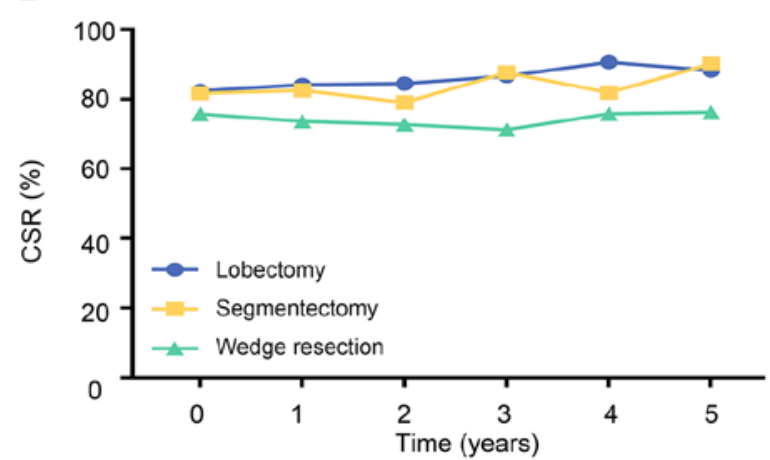

Number at risk:

$\begin{array}{lllllll}- & 538 & 431 & 362 & 281 & 239 & 194 \\ - & 71 & 61 & 54 & 38 & 28 & 20 \\ - & 295 & 240 & 186 & 140 & 110 & 81\end{array}$
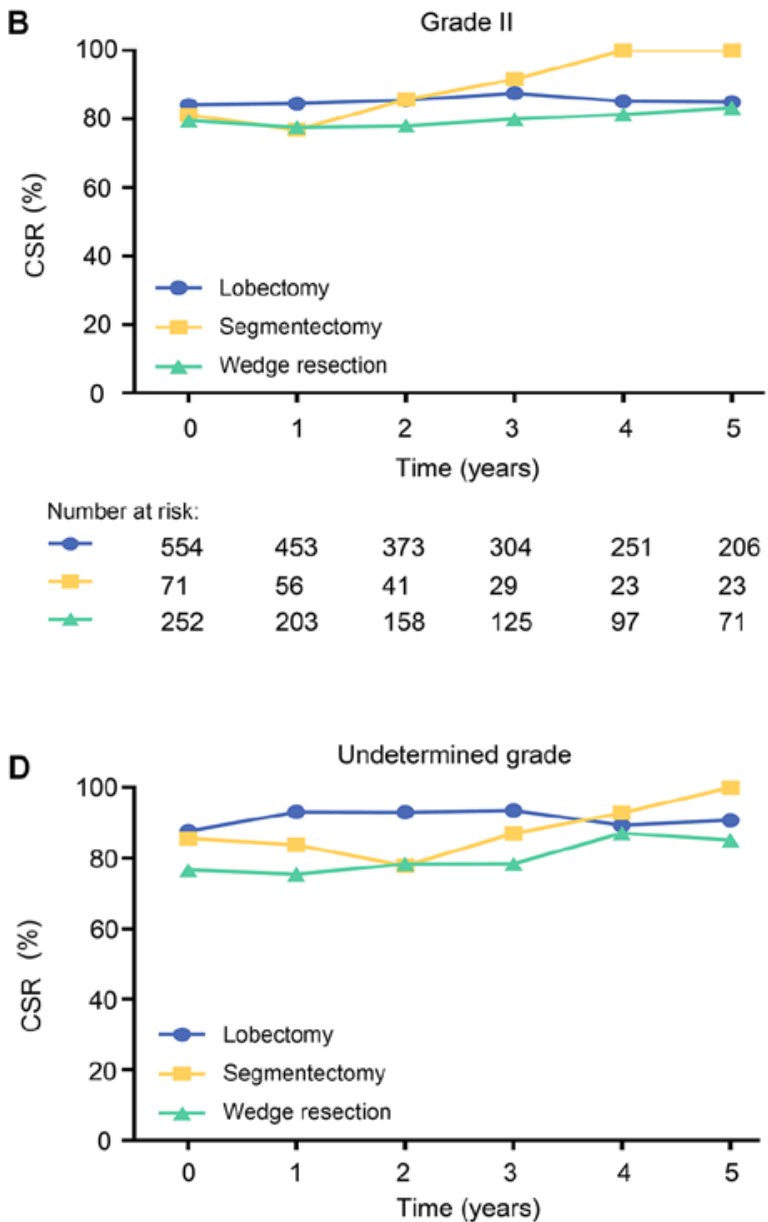

$\begin{array}{ccccccc}\text { Number at risk: } & & & & & \\ - & 179 & 142 & 117 & 96 & 90 & 74 \\ - & 24 & 23 & 23 & 18 & 16 & 14 \\ - & 142 & 111 & 86 & 67 & 51 & 41\end{array}$

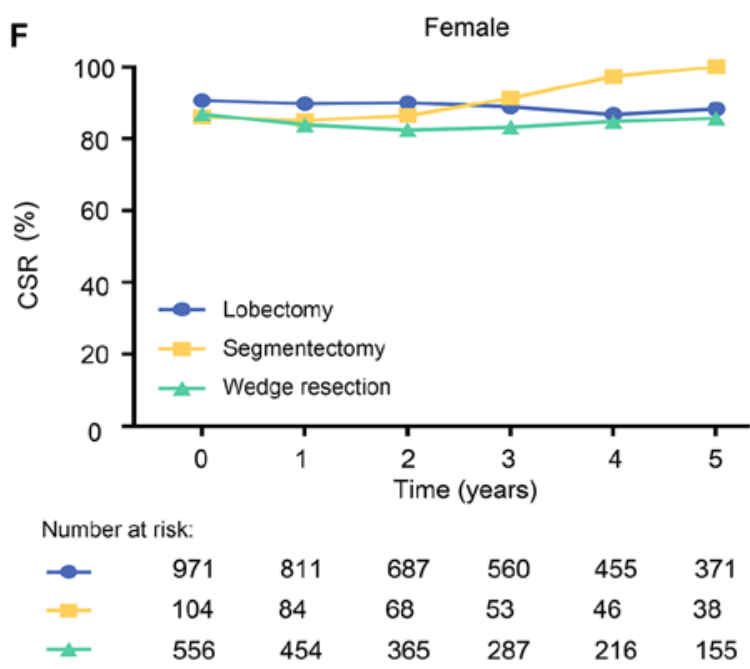

Figure 6. Comparison of CSR among three surgical procedures based on stratification according to grade and gentle. The changes in 3-year CSR of (A) Grade I, (B) II, (C) III-IV, (D) undetermined grade; (E) male; and (F) female. CSR, conditional survival rate.

In conclusion, to the best of our knowledge, the present study is the first to compare CSR concerning lobectomy, segmentectomy and wedge resection for patients with stage IA1 NSCLC. Consequently, these findings suggested that lobectomy is the most conservative surgical procedure for stage IA1 NSCLC. Additionally, the present findings pose interesting questions regarding the better long-term prognosis of segmentectomy in specific subsets of patients, such as females, patients $\geq 66$ years 
old, patients with squamous cell carcinoma or poor differentiation. Overall, the present study may contribute to improving treatment decision-making and update the prognosis of those patients with stage IA1 NSCLC.

\section{Acknowledgements}

Not applicable.

\section{Funding}

No funding was received.

\section{Availability of data and materials}

The datasets generated and/or analyzed during the current study are available in the Surveillance Epidemiology and End Results repository (https://seer.cancer.gov).

\section{Authors' contributions}

SX, CY, XF, YB and YL conceived and designed the present study. SX, CY, XF and YB collected and assembled the data. All authors analyzed and interpreted the data, drafted and proofread the initial manuscript, and have read and approved the manuscript.

\section{Ethics approval and consent to participate}

Not applicable.

\section{Patient consent for publication}

Not applicable.

\section{Competing interests}

The authors declare that they have no competing interests.

\section{References}

1. National Lung Screening Trial Research Team; Church TR, Black WC, Aberle DR, Berg CD, Clingan KL, Duan F, Fagerstrom RM, Gareen IF, Gierada DS, et al: Results of initial low-dose computed tomographic screening for lung cancer. N Engl J Med 368: 1980-1991, 2013.

2. Ginsberg RJ and Rubinstein LV: Randomized trial of lobectomy versus limited resection for T1 N0 non-small cell lung cancer Lung Cancer Study Group. Ann Thorac Surg 60: 615-622, 1995

3. Dai C, Shen J, Ren Y, Zhong S, Zheng H, He J, Xie D, Fei K, Liang W, Jiang G, et al: Choice of surgical procedure for patients with non-small-cell lung Cancer $</=1 \mathrm{~cm}$ or $>1$ to $2 \mathrm{~cm}$ among lobectomy, segmentectomy, and wedge resection: A population-based study. J Clin Oncol 34: 3175-3182, 2016.

4. Widder J, Van De Wauwer C and Langendijk JA: Lobectomy or sublobectomy for small non-small-cell lung cancer: The question remains. J Clin Oncol 35: 572-573, 2017.

5. Cao C, Chandrakumar D, Gupta S, Yan TD and Tian DH: Could less be more? A systematic review and meta-analysis of sublobar resections versus lobectomy for non-small cell lung cancer according to patient selection. Lung Cancer 89: 121-132, 2015.

6. Altorki NK, Yip R, Hanaoka T, Bauer T, Aye R, Kohman L, Sheppard B, Thurer R, Andaz S, Smith M, et al: Sublobar resection is equivalent to lobectomy for clinical stage 1A lung cancer in solid nodules. J Thorac Cardiovasc Surg 147: 754-762, 2014.
7. Fiorelli A, Caronia FP, Daddi N, Loizzi D, Ampollini L, Ardo N, Ventura L, Carbognani P, Potenza R, Ardissone F, et al: Sublobar resection versus lobectomy for stage I non-small cell lung cancer: An appropriate choice in elderly patients? Surg Today 46: 1370-1382, 2016.

8. Kodama K, Doi O, Higashiyama M and Yokouchi H: Intentional limited resection for selected patients with T1 N0 M0 non-small-cell lung cancer: A single-institution study. J Thorac Cardiovasc Surg 114: 347-353, 1997.

9. Koike T, Yamato Y, Yoshiya K, Shimoyama T and Suzuki R: Intentional limited pulmonary resection for peripheral T1 N0 M0 small-sized lung cancer. J Thorac Cardiovasc Surg 125: 924-928, 2003.

10. Bao F, Ye P, Yang Y, Wang L, Zhang C, Lv X and Hu J: Segmentectomy or lobectomy for early stage lung cancer: A meta-analysis. Eur J Cardiothorac Surg 46: 1-7, 2014.

11. Donahue JM, Morse CR, Wigle DA, Allen MS, Nichols FC, Shen KR, Deschamps C and Cassivi SD: Oncologic efficacy of anatomic segmentectomy in stage IA lung cancer patients with T1a tumors. Ann Thorac Surg 93: 381-387, 2012.

12. Kates M, Swanson S and Wisnivesky JP: Survival following lobectomy and limited resection for the treatment of stage I non-small cell lung cancer $<=1 \mathrm{~cm}$ in size: A review of SEER data. Chest 139: 491-496, 2011.

13. Harada H, Okada M, Sakamoto T, Matsuoka H and Tsubota N: Functional advantage after radical segmentectomy versus lobectomy for lung cancer. Ann Thorac Surg 80: 2041-2045, 2005.

14. Detterbeck FC, Boffa DJ, Kim AW and Tanoue LT: The eighth edition lung cancer stage classification. Chest 151: 193-203, 2017.

15. Cao J, Yuan P, Wang Y, Xu J, Yuan X, Wang Z, Lv W and Hu J: Survival rates after lobectomy, segmentectomy, and wedge resection for non-small cell lung cancer. Ann Thorac Surg 105: 1483-1491, 2018

16. Callister ME, Baldwin DR, Akram AR, Barnard S, Cane P, Draffan J, Franks K, Gleeson F, Graham R, Malhotra P, et al: British Thoracic Society guidelines for the investigation and management of pulmonary nodules. Thorax 70 (Suppl 2): ii1-ii54, 2015.

17. Merrill RM, Henson DE and Barnes M: Conditional survival among patients with carcinoma of the lung. Chest 116: 697-703, 1999.

18. Henson DE and Ries LA: On the estimation of survival. Semin Surg Oncol 10: 2-6, 1994.

19. Wang SJ, Fuller CD and Thomas CR Jr: Ethnic disparities in conditional survival of patients with non-small cell lung cancer. J Thorac Oncol 2: 180-190, 2007.

20. National Cancer Institute: Surveillance, Epidemiology, and End Results. http://www.seer.cancer.gov.

21. Stuart EA, Lee BK and Leacy FP: Prognostic score-based balance measures can be a useful diagnostic for propensity score methods in comparative effectiveness research. J Clin Epidemiol 66 (Suppl 8): S84-S90.e1, 2013.

22. Austin PC: Statistical criteria for selecting the optimal number of untreated subjects matched to each treated subject when using many-to-one matching on the propensity score. Am J Epidemiol 172: 1092-1097, 2010.

23. R Core Team (2012). R: A language and environment for statistical computing. R Foundation for Statistical Computing, Vienna, Austria. ISBN 3-900051-07-0, URL http://www.R-project.org/.

24. Miller DL, Rowland CM, Deschamps C, Allen MS, Trastek VF and Pairolero PC: Surgical treatment of non-small cell lung cancer $1 \mathrm{~cm}$ or less in diameter. Ann Thorac Surg 73: 1545-1550, 2002.

25. Zhang Y, Sun Y, Wang R, Ye T, Zhang Y and Chen H: Meta-analysis of lobectomy, segmentectomy, and wedge resection for stage I non-small cell lung cancer. J Surg Oncol 111: 334-340, 2015

26. Cao C, Gupta S, Chandrakumar D, Tian DH, Black D and Yan TD: Meta-analysis of intentional sublobar resections versus lobectomy for early stage non-small cell lung cancer. Ann Cardiothorac Surg 3: 134-141, 2014.

27. Groth SS, Rueth NM, Hodges JS, Habermann EB, Andrade RS, D'Cunha J and Maddaus MA: Conditional cancer-specific versus cardiovascular-specific survival after lobectomy for stage I non-small cell lung cancer. Ann Thorac Surg 90: 375-382, 2010.

28. Rodin G, Lo C, Rydall A, Shnall J, Malfitano C, Chiu A, Panday T, Watt S, An E, Nissim R, et al: Managing cancer and living meaningfully (CALM): A randomized controlled trial of a psychological intervention for patients with advanced cancer. J Clin Oncol 36: 2422-2432, 2018. 
29. Khullar OV, Liu Y, Gillespie T, Higgins KA, Ramalingam S Lipscomb J and Fernandez FG: Survival after sublobar resection versus lobectomy for clinical stage IA Lung Cancer: An analysis from the national cancer data base. J Thorac Oncol 10: 1625-1633, 2015.

30. Sihoe AD and Van Schil P: Non-small cell lung cancer: When to offer sublobar resection. Lung Cancer 86: 115-120, 2014.

31. Liang W, He J, Shen Y, Shen J, He Q, Zhang J, Jiang G, Wang Q, Liu L, Gao S, et al: Impact of examined lymph node count on precise staging and long-term survival of resected non-small-cell lung cancer: A population study of the US SEER database and a Chinese Multi-Institutional Registry. J Clin Oncol 35: 1162-1170, 2017.

32. Tong BC, Kosinski AS, Burfeind WR Jr, Onaitis MW, Berry MF, Harpole DH Jr and D'Amico TA: Sex differences in early outcomes after lung cancer resection: Analysis of the Society of Thoracic Surgeons General Thoracic Database. J Thorac Cardiovasc Surg 148: 13-18, 2014.

33. Paleari L, Russo P, Cesario A and Granone P: Factors predicting poor survival after resection of stage IA non-small cell lung cancer. J Thorac Cardiovasc Surg 136: 241-242, 2008.
34. Kozower BD, Sheng S, O'Brien SM, Liptay MJ, Lau CL, Jones DR, Shahian DM and Wright CD: STS database risk models: Predictors of mortality and major morbidity for lung cancer resection. Ann Thorac Surg 90: 875-881, 2010.

35. Bosco JL, Silliman RA, Thwin SS, Geiger AM, Buist DS, Prout MN, Yood MU, Haque R, Wei F and Lash TL: A most stubborn bias: No adjustment method fully resolves confounding by indication in observational studies. J Clin Epidemiol 63: 64-74, 2010.

36. NCCN Clinical Practice Guidelines in Oncology. Non-small cell lung cancer (v.2.2013). Available at: http://www.ncen. org/professionals/physician_gls/pdf/nscl.pdf. Accessed May 1, 2016.

This work is licensed under a Creative Commons Attribution-NonCommercial-NoDerivatives 4.0 International (CC BY-NC-ND 4.0) License. 